\title{
Characterisation of Nano-Calcium Lactate from Chicken Eggshells Synthesized by Precipitation Method as Food Supplement
}

\author{
Prayitno $\mathrm{AH}^{1,2}$, Siswoyo $\mathrm{TA}^{3}$, Erwanto $\mathrm{Y}^{4}$, Lindriati $\mathrm{T}^{5}$, Hartatik $\mathrm{S}^{3}$, Aji JMM ${ }^{3}$, Suryanto $\mathrm{E}^{4}, \mathrm{Rusman}^{4}$ \\ 'Department of Animal Science, Politeknik Negeri Jember, Jember, Indonesia \\ ${ }^{2}$ Doctoral Study Program of Agricultural Science, Faculty of Agriculture, University of Jember, Jember, Indonesia \\ ${ }^{3}$ Faculty of Agriculture, University of Jember, Jember, Indonesia \\ ${ }^{4}$ Faculty of Animal Science, Gadjah Mada University, Sleman, Indonesia \\ ${ }^{3}$ Faculty of Agricultural Technology, University of Jember, Jember, Indonesia \\ E-mail: agushp@polije.ac.id
}

(received 10-07-2022; revised 13-01-2022; accepted 20-01-2022)

\begin{abstract}
ABSTRAK
Prayitno AH, Siswoyo TA, Erwanto Y, Lindriati T, Hartatik S, Aji JMM, Suryanto E, Rusman. 2021. Karakterisasi nano kalsium laktat dari kerabang telur ayam yang disintesis melalui metode presipitasi sebagai bahan suplemen pangan. JITV 26(4):139-144. DOI: http//dx.doi.org/10.14334/jitv.v26i4.2828.

Osteoporosis dapat dicegah dengan mengkonsumsi kalsium laktat. Kalsium yang dikonsumsi pada umumnya berukuran mikro. Kalsium berukuran mikro hanya terserap oleh tubuh sekitar 50\% yang dapat mengakibatkan terjadinya defisiensi. Nanoteknologi telah dikembangkan untuk peningkatan absorbsi kalsium dalam ukuran nano. Penelitian ini bertujuan untuk mensintesis nanokalsium laktat dari kalsium oksida kerabang telur ayam dan kalsium oksida komersial melalui metode presipitasi. Sintesis dilakukan dengan mereaksikan larutan $1 \mathrm{~mol} / \mathrm{L}$ kalsium oksida kerabang telur dan kalsium oksida komersial (kontrol) sebanyak $20 \mathrm{ml}$ dicampur larutan $6 \mathrm{~mol} / \mathrm{L}$ asam laktat sebanyak $30 \mathrm{ml}$ dengan perbandingan 1:1,5 (v/v) selama 30 menit pada suhu $50^{\circ} \mathrm{C}$ dan diaduk menggunakan magnetic stirrer dengan kecepatan $500 \mathrm{rpm} / \mathrm{menit}$. Etanol $50 \%$ ditambahkan sebanyak $20 \mathrm{ml}(\mathrm{v} / \mathrm{v})$, dioven pada suhu $105^{\circ} \mathrm{C}$ selama 72 jam kemudian dihaluskan untuk memperoleh serbuk nanokalsium laktat (NCaL). Karakterisasi NCaL menggunakan Transmission electron microscopy (TEM), X-ray diffraction (XRD), dan Fourier transform infrared (FTIR). Hasil penelitian menunjukkan bahwa kerabang telur ayam dapat disintesis dengan metode presipitasi menjadi NCaL berupa kristal berwarna putih. Karakterisasi dengan XRD menunjukkan bahwa sudut difraksi $2 \theta$ dengan puncak dari $\mathrm{NCaL}$ yaitu $9,3800^{\circ}, 10,3869^{\circ}$, dan $22,9570^{\circ}$. Karakterisasi dengan FTIR diperoleh puncak pada bilangan gelombang dari NCaL yaitu 1.589,34 cm-1. Karakterisasi dengan TEM menunjukkan bahwa ukuran kristal NCaL yaitu sebesar $75 \mathrm{~nm}$.
\end{abstract}

Kata Kunci: Kerabang telur ayam, Bahan suplemen pangan, Nanokalsium laktat, Metode presipitasi

\section{ABSTRACT}

Prayitno AH, Siswoyo TA, Erwanto Y, Lindriati T, Hartatik S, Aji JMM, Suryanto E, Rusman. 2021. Characterisation of nanocalcium lactate from chicken eggshells synthesized by precipitation method as a food supplement. JITV 26(4):139-144. DOI: http//dx.doi.org/10.14334/jitv.v26i4.2828.

Osteoporosis can be prevented by consuming calcium lactate. Calcium that is consumed is generally in a micro-size. Microsized calcium is only absorbed by the body by about $50 \%$ which can cause deficiency. Eggshells are poultry waste that is rich in calcium and can be used as a cheap source of dietary calcium through nanotechnology. Nanotechnology has been developed to increase calcium absorption. This study aimed to synthesize nano-calcium lactate from chicken eggshells, and commercial calcium oxide by precipitation method. Synthesis was carried out by reacting a solution of $1 \mathrm{~mol} / \mathrm{L}$ eggshell calcium oxide and commercial calcium oxide (control) as much as $20 \mathrm{ml}$ mixed with a solution of $6 \mathrm{~mol} / \mathrm{L}$ lactic acids as much as $30 \mathrm{ml}$ with a ratio of $1: 1.5(\mathrm{v} / \mathrm{v})$ for 30 minutes at $50^{\circ} \mathrm{C}$ at a speed of $500 \mathrm{rpm} /$ minute using a magnetic stirrer. Ethanol $50 \%$ was added as much as $20 \mathrm{ml}(\mathrm{v} / \mathrm{v})$, oven-dried at $105^{\circ} \mathrm{C}$ for 72 hours then crushed to produce eggshell nano-calcium lactate (NCaL) powder. Characterisation of NCaL using Transmission electron microscopy (TEM), X-ray diffraction (XRD), and Fourier transform infrared (FTIR). Result showed that NCaL in the form of white crystals could be synthesized from chicken eggshells by precipitation method. Characterization with XRD showed that the diffraction angle was $2 \theta$ with the peaks of NCaL, namely $9.3800^{\circ}, 10.3869^{\circ}$, and $22.9570^{\circ}$. Characterization with FTIR obtained a peak in the wavenumber from NCaL, namely $1,589.34$ $\mathrm{cm}^{-1}$. Characterization using TEM showed that the crystal size of NCaL was $75 \mathrm{~nm}$.

Key Words: Chicken eggshell, Food supplement, Nano-calcium lactate, Precipitation method

\section{INTRODUCTION}

Calcium is the most abundant reserved nutrient in the human body (Wiria et al. 2020). Lack of calcium in food is a common problem (Brun et al. 2013) that can lead to osteoporosis (Bradauskiene et al. 2017) and bone loss (Wiria et al. 2020). One of the efforts that can be done to prevent osteoporosis is by taking calcium 
supplements (Lee et al. 2017; Paschalis et al. 2017) Osteoporosis can be prevented as early as possible by consuming foods rich in calcium such as milk and dairy products (Caroli et al. 2011).

However, people do not usually consume them in appropriate amounts according to clinical guidelines and on the other hand calcium tablet supplements are expensive (Brun et al. 2013). Even though there are other sources of calcium that have the potential to contain higher calcium than milk, namely eggshells. The eggshell is rich in calcium carbonate which is about 96-97\% (Intharapat et al. 2013). The economic value and properties of eggshells can be increased through the application of nanotechnology. The chemical precipitation method produced lactate nano-calcium with a particle size of 55 to $100 \mathrm{~nm}$ ( $\mathrm{Li}$ et al. 2009; Wang et al. 2012).

Materials synthesized in nano size have better performance with increasing surface area (Habte et al. 2019). The calcium lactate is widely used as fortification of calcium with a high absorption rate for the food and pharmaceutical industry (Cheong 2016) which is recognized as safe for use as a texturizer and thickener (Catherina et al. 2016), antibacterial (Yuk et al. 2008), and to preserve and prolong. age of processed meat products (Baston \& Barna 2013). Nano-sized materials can cause the extract to dissolve easily and have a high absorption efficiency in the intestine (Gunasekaran et al. 2014).

The formation of nanomaterials by precipitation method is considered cheap, easy, environmentally friendly (Habte et al. 2019), and time saving (You \& Xu 2021). Nanotechnology has been developed to increase the absorption rate of calcium in the body (Mosaddegh \& Hassankhani 2014; Ferraz et al. 2018; Jirimali et al. 2018). Eggshells can be purified as a source of calcium which can be used as a food supplement (Laohavisuti et al. 2021). The eggshell particle size can be optimized through nanotechnology applications. Nano-calcium lactate from chicken eggshells as novelty can be used as a natural source of calcium as a food supplement. However, there is no scientific supporting data on this matter. Therefore, this study aimed to determine the synthesis of nano-calcium lactate from chicken eggshell by precipitation method.

\section{MATERIALS AND METHODS}

\section{Eggshell calcium oxide preparation}

Preparation of eggshell calcium oxide was done according to Prayitno et al. (2016). The brown chicken eggshell was cleaned from the eggshell membrane and washed. Eggshells were boiled for 2 hours then ovendried at $95^{\circ} \mathrm{C}$ for 24 hours. The dried eggshells were ground and sieved ( 80 mesh filter size). The powder was then calcined at $1,000^{\circ} \mathrm{C}$ for 2 hours to gain calcium oxide $(\mathrm{CaO})$ powder.

\section{Nano-calcium lactate preparation}

This study compared the synthesis of nano-calcium lactate using brown chicken eggshell calcium oxide and commercial calcium oxide (control) obtained from the Integrated Research and Testing Laboratory (LPPT) Universitas Gadjah Mada. Synthesis of nano-calcium lactate by precipitation method according to Prayitno et al. (2016). A solution of $1 \mathrm{~mol} / \mathrm{L}$ eggshell $\mathrm{CaO}$ and commercial $\mathrm{CaO}$ (control) $20 \mathrm{ml}$ mixed with a solution of $6 \mathrm{~mol} / \mathrm{L}$ lactic acids as much as $30 \mathrm{ml}$ with a ratio of $1: 1.5(\mathrm{v} / \mathrm{v})$ for 30 minutes at $50^{\circ} \mathrm{C}$ at a speed of 500 $\mathrm{rpm} /$ minute using a magnetic stirrer. Ethanol $50 \%$ was added as much as $20 \mathrm{ml}(\mathrm{v} / \mathrm{v})$, dried in an oven at $105^{\circ} \mathrm{C}$ for 72 hours then crushed to produce eggshell nanocalcium lactate $(\mathrm{NCaL})$ powder.

\section{Characterization of nano-calcium lactate}

The NCaL characterization tested included Fourier transform infrared (FTIR) and X-ray diffraction (XRD) according to Dheyab et al. (2020), and Transmission electron microscopy (TEM) according to Nguyen et al. (2018).

\section{RESULTS AND DISCUSSION}

\section{Fourier transform infrared}

There are three types of physical characterization methods of nanoparticles, namely crystallography, microscopy, and spectroscopy methods. Crystallography using $\mathrm{X}$-rays is very useful for identifying isomorphic crystals, namely crystals that have the same structure but differ in their geometric patterns. Characterization by spectroscopy can use emission photos, magnetic resonance spectroscopy, Fourier transform infrared (FTIR), and X-ray diffraction (XRD) (Nasrollahzadeh et al. 2019).

FTIR is used to identify complex groups in compounds but cannot determine the constituent elements of them. In FTIR, infrared radiation is passed through the sample. Some of the infrared radiation is absorbed by the sample and some are transmitted. If the frequency of a specific vibration is equal to the frequency of infrared radiation directing the molecule, the molecule will absorb that radiation. The result on spectrum describes molecular absorption and transmission. This transmission forms a molecular fingerprint of a sample and because it is a fingerprint there are no two unique molecular structures that 
produce the same infrared spectrum (Delmifiana \& Astuti 2013).

Results of the FTIR test presented in Figure 1 (a) was result of infrared spectroscopy of eggshells that was calcined at $1,000^{\circ} \mathrm{C}$. The most mineral content in eggshells is calcium carbonate $\left(\mathrm{CaCO}_{3}\right)$. Calcium carbonate that was calcined at $1000^{\circ} \mathrm{C}$ will undergo the decomposition of organic compounds so that the form changes from calcium carbonate to calcium oxide (CaO) (Rivera et al. 1999; Adak \& Purohit 2011). This can be seen by the suitability of the location of the wavenumbers between the groups contained in the eggshell which has been heated at $1000^{\circ} \mathrm{C}$ with the FTIR spectra of commercial calcium oxide as shown in Figure 1 (b). FTIR spectra of eggshells heated at $1000^{\circ} \mathrm{C}$ are found at wave number $1489.05 \mathrm{~cm}^{-1}$ as



(a) shown in Figure 1 (a) and approach the FTIR spectra of commercial calcium oxide, namely at wave number $1427.32 \mathrm{~cm}^{-1}$ as presented in Figure 2 (b).

The reaction process of calcium lactate from eggshell and commercial calcium oxide with lactic acid has been formed. This can be seen by the suitability of the location of the wavenumbers between the groups contained in calcium lactate based on SDBS as shown in Figure 2 (a), Figure 2 (b), and Figure 3. Figure 3 shows the wavenumber of $1.582 \mathrm{~cm}^{-1}$ corresponds to the FTIR spectra of the eggshell calcium oxide which has been reacted with lactic acid, which is found in the wavenumber of $1.589 .34 \mathrm{~cm}^{-1}$ as shown in Figure 2 (a) and is almost the same as the FTIR spectra of calcium oxide. The commercial calcium oxide that has been reacted with lactic acid has the wavenumber $1,589.34 \mathrm{~cm}^{-1}$

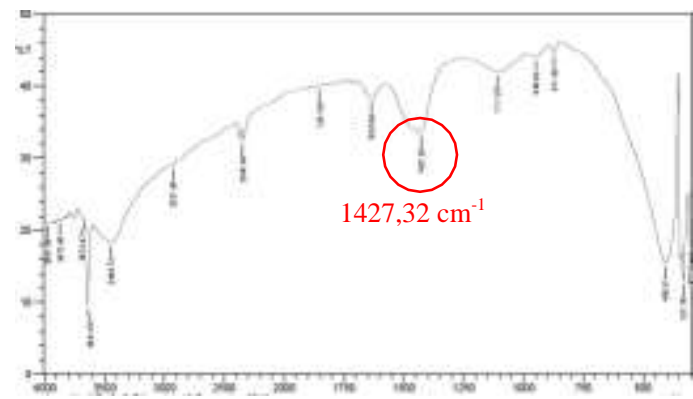

(b)

Figure 1. The location of the wavenumber of calcined eggshells at $1,000^{\circ} \mathrm{C}$ (a) and commercial $\mathrm{CaO}$ (b) measured by FTIR spectra

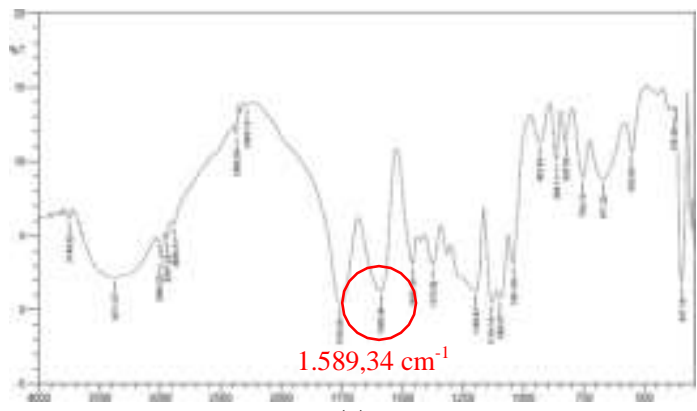

(a)

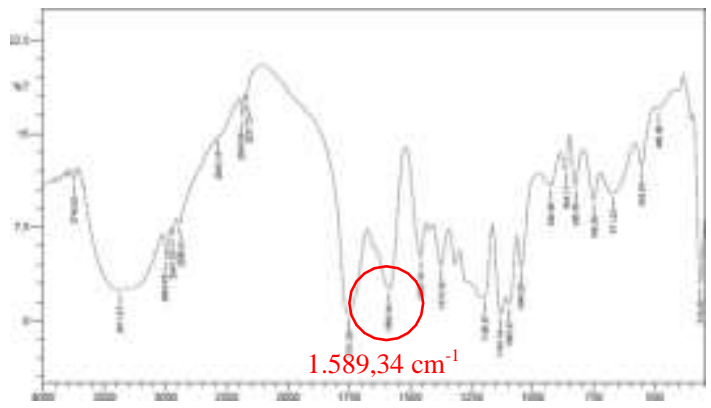

(b)

Figure 2. The location of the wavenumber of calcium lactate with eggshell $\mathrm{CaO}$ (a) and calcium lactate with commercial $\mathrm{CaO}$ (b) measured by FTIR spectra

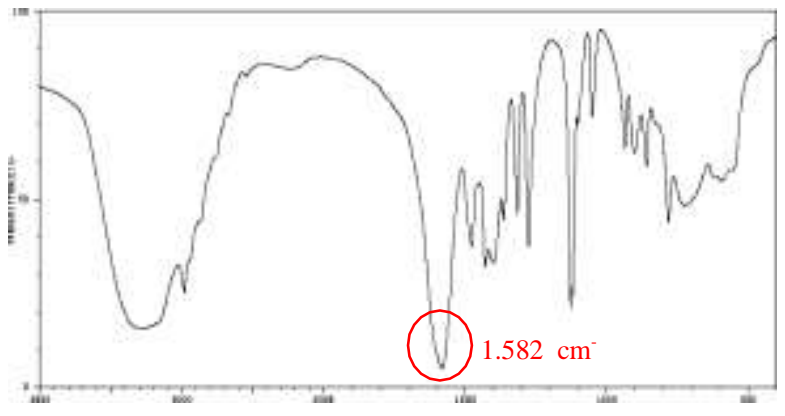

Figure 3. Spectral database (SDBS) cium lactate 
as shown in Figure 2 (b). This indicates that both commercial and eggshell calcium oxide which has been reacted with lactic acid has produced calcium lactate.

\section{X-ray diffraction}

$\mathrm{X}$-ray diffraction (XRD) is used to determine the value of lattice parameters, crystal structure, and degree of crystallinity. The degree of crystallization is a quantity that states the amount of crystal content in a

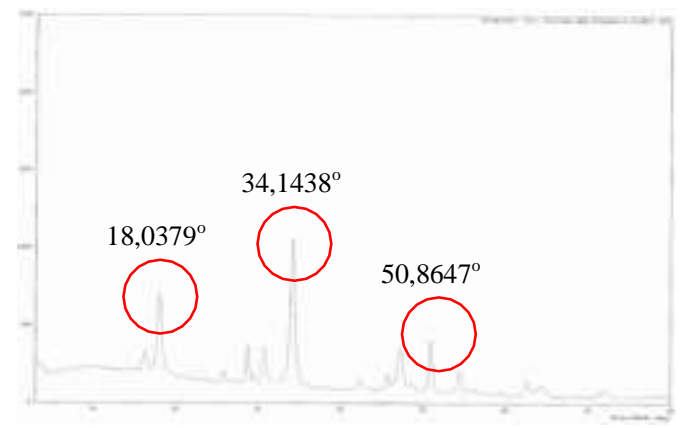

(a) material by comparing the area of the peak curve with the total area of amorphous and crystalline (Fitri et al. 2017). Analysis using the principle of X-ray emission produced by the collision of electrons and atoms of $\mathrm{Cr}$, $\mathrm{Fe}, \mathrm{Co}, \mathrm{Cu}, \mathrm{Mo}$, or $\mathrm{W}$. XRD analysis provide information about the sample structure such as lattice parameters, orientation, and the crystal system. XRD analysis is also useful for identifying semi-quantitative sample phases, by calculating the volume fraction of a sample and the ratio of the crystalline area fraction to the total area fraction (Nasrollahzadeh et al. 2019).

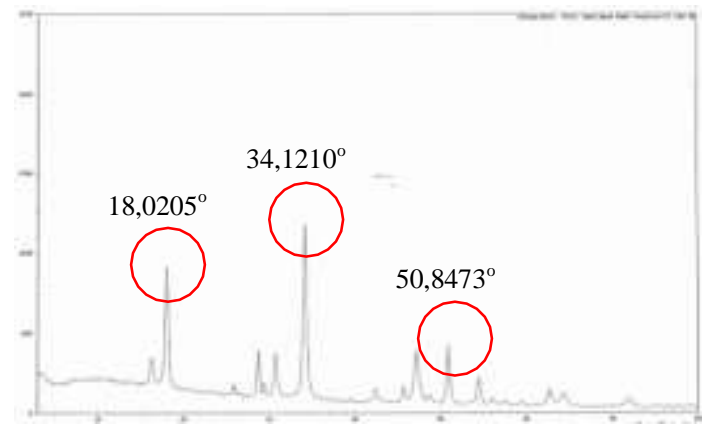

(b)

Figure 4. The diffraction angle of calcined eggshells at $1,000^{\circ} \mathrm{C}$ (a) and commercial $\mathrm{CaO}(\mathrm{b})$.

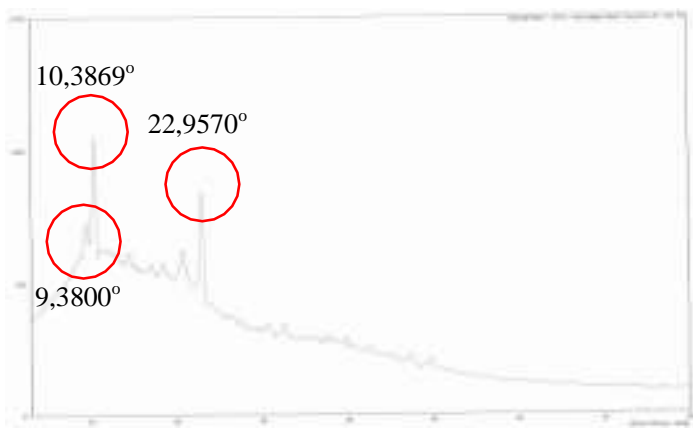

(a)

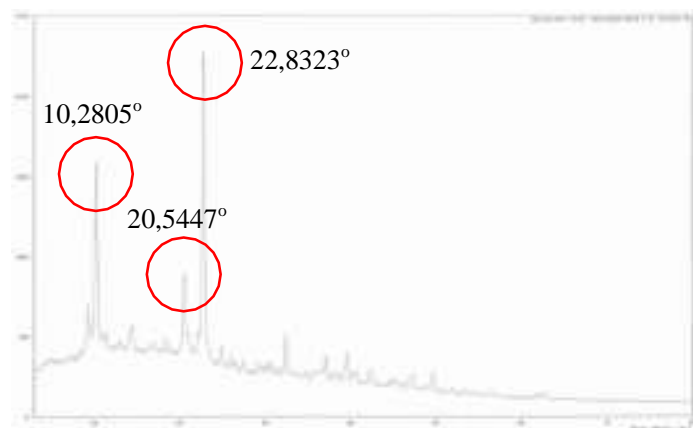

(b)

Figure 5. The diffraction angle of calcined eggshells at $1,000^{\circ} \mathrm{C}$ (a) and commercial $\mathrm{CaO}$ (b).

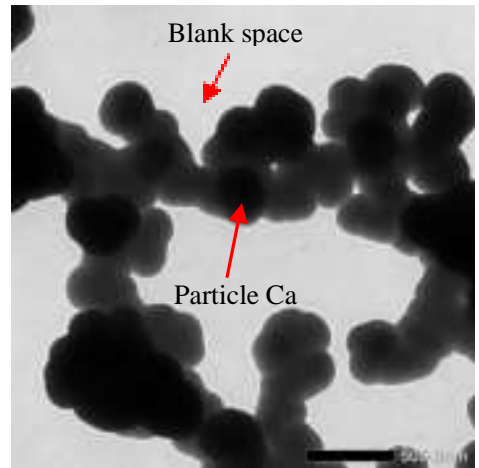

(a)

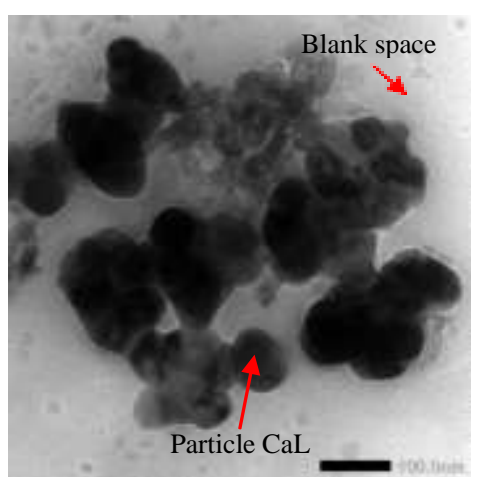

(b)

Figure 6. The morphology and ultrastructures of calcined eggshell at $1,000^{\circ} \mathrm{C}$ with a magnification of $10,000 \times$ (a) and eggshell calcium lactate with a magnification of 40,000 x (b). 
XRD results of eggshells heated at a temperature of $1,000^{\circ} \mathrm{C}$ showed a diffraction angle of $2 \theta$ with peaks of $18.0379^{\circ}, 34.1438^{\circ}$, and $50.8647^{\circ}$ as shown in Figure 4 (a) there was a similarity with the peaks of commercial $\mathrm{CaO}$ with the diffraction angle of $2 \theta$ with peaks $18,0205^{\circ}, 34,1210^{\circ}$, and $50,8473^{\circ}$ as shown in Figure 4 (b). Therefore, the eggshell calcined at $1,000^{\circ} \mathrm{C}$ has produced calcium oxide. Pongtonglor et al. (2011)reported that $\mathrm{CaCO}_{3}$ from eggshells heated at high temperatures $1,300^{\circ} \mathrm{C}$ turned into $\mathrm{CaO}$. Calcium carbonate from the eggshell turns into $\mathrm{CaO}$ by releasing carbon dioxide $\left(\mathrm{CO}_{2}\right)$ as it decomposed (Rivera et al. 1999; Adak \& Purohit 2011) as shown in the equation as follow:

$$
\mathrm{CaCO}_{3} \rightarrow \mathrm{CaO}+\mathrm{CO}_{2}
$$

XRD results of eggshell calcium oxide reacted with lactic acid showed a diffraction angle of $2 \theta$ with peaks of $9.3800^{\circ}, 10.3869^{\circ}$, and $22.9570^{\circ}$ as shown in Figure 5 (a). XRD results of commercial calcium oxide reacted with lactic acid showed a diffraction angle of $2 \theta$ with peaks of $10.2805^{\circ}, 20.5447^{\circ}$, and $22.8323^{\circ}$ as shown in Figure 5 (b). There are similarities in the two peaks at the diffraction angle of $2 \theta$ both in eggshell and commercial calcium oxide which was reacted with lactic acid to form calcium lactate $(\mathrm{CaL})$.

\section{Transmission electron microscopy}

The morphology and ultrastructures of eggshell calcium and eggshell calcium lactate are presented in Figures 6 (a) and (b). The uniformity of shape and size of eggshell calcium and eggshell calcium lactate looks the same. The TEM test results showed that the eggshell calcium particle size was known to be about $300 \mathrm{~nm}$ as shown in Figure 6 (a).

The TEM test results obtained that the eggshell calcium lactate particle size was $75 \mathrm{~nm}$ as shown in Figure 6 (b). Li et al. (2009) and Wang et al. (2012) reported that through the chemical precipitation method, calcium lactate nanoparticles were produced with a particle size of 55 to $100 \mathrm{~nm}$. Abdullah et al. (2008) stated that nanoparticle synthesis means the manufacture of particles with a size of less than $100 \mathrm{~nm}$ and at the same time changing their properties or functions.

\section{CONCLUSION}

Nano-calcium lactate could be synthesized by the precipitation method form chicken eggshells resulted in white crystals. Characterization with XRD showed that the diffraction angle was $2 \theta$ with the peaks of $\mathrm{NCaL}$, namely $9.3800^{\circ}, 10.3869^{\circ}$, and $22.9570^{\circ}$. FTIR obtained a peak in the wavenumber from $\mathrm{NCaL}$, namely
$1,589.34 \mathrm{~cm}^{-}{ }^{1}$. TEM showed that the crystal size of $\mathrm{NCaL}$ was $75 \mathrm{~nm}$. The eggshell nano-calcium lactate can be used as a food supplement with a high absorption rate.

\section{REFERENCES}

Abdullah M, Virgus Y, Nirmin, Khairurrijal. 2008. Review: sintesis nanomaterial. J Nanosains Nanoteknologi. 1:33-57.

Adak MD, Purohit KM. 2011. Synthesis of nano-crystalline hydroxyapatite from dead snail shells for biological implantation. Trends Biomater Artif Organs. 25:101106.

Baston O, Barna O. 2013. Calcium lactate influence on some non-pathogenic microorganisms. Food Environ Saf. 12:278-283.

Bradauskiene V, Montrimaite K, Moscenkova E. 2017. Facilities of bread enrichment with calcium by using eggshell powder. In: 11th Balt Conf Food Sci Technol "Food Sci Technol a Chang world." Jelgava (Latvia): Baltic Conference on Food Science and Technology: Conference Proceedings; p. 91-95.

Brun LR, Lupo M, Delorenzi DA, Di Loreto VE, Rigalli A. 2013. Chicken eggshell as suitable calcium source at home. Int J Food Sci Nutr. 64:740-743. DOI: 10.3109/09637486.2013.787399.

Caroli A, Poli A, Ricotta D, Banfi G, Cocchi D. 2011. Invited review: Dairy intake and bone health: A viewpoint from the state of the art1. J Dairy Sci. 94:5249-5262. DOI: 10.3168/jds.2011-4578.

Catherina CI, Surjoseputro S, Setijawati E. 2016. Pengaruh konsentrasi perendaman kalsium laktat terhadap sifat fisikokimia mashed sweet potato powder. J Teknol Pangan dan Gizi. 15:65-71.

Cheong SH. 2016. Physicochemical properties of calcium lactate prepared by single-phase aragonite precipitated calcium carbonate. Res J Pharm, Biol Chem Sci. 7:1786-1794

Delmifiana B, Astuti. 2013. Pengaruh sonikasi terhadap struktur dan morfologi nanopartikel magnetik yang disintesis dengan metode kopresipitasi. J Fis Unand. 2:186-189. DOI: 10.25077/jfu.2.3.\%25p.2013.

Dheyab MA, Aziz AA, Jameel MS, Noqta OA, Khaniabadi PM, Mehrdel B. 2020. Simple rapid stabilization method through citric acid modification for magnetite nanoparticles. Sci Rep. 10:1-8.

Ferraz E, Gamelas JAF, Coroado J, Monteiro C, Rocha F. 2018. Eggshell waste to produce building lime: calcium oxide reactivity, industrial, environmental and economic implications. Mater Struct Constr. 51. DOI: 10.1617/s11527-018-1243-7.

Fitri N, Yusibani E, Yufita E. 2017. Identifikasi mineral pada material perekat benteng purba di Kawasan Aceh Besar menggunakan XRD. J Aceh Phys Soc. 6:1-4. 
Gunasekaran T, Haile T, Nigusse T, Dhanaraju MD. 2014. Nanotechnology: An effective tool for enhancing bioavailability and bioactivity of phytomedicine. Asian Pac J Trop Biomed. 4:S1-S7. DOI: 10.12980/APJTB.4.2014C980.

Habte L, Shiferaw N, Mulatu D, Thenepalli T, Chilakala R, Ahn JW. 2019. Synthesis of nano-calcium oxide from waste eggshell by sol-gel method. Sustain. 11:1-10. DOI: $10.3390 /$ su11113196.

Intharapat P, Kongnoo A, Kateungngan K. 2013. The potential of chicken eggshell waste as a bio-filler filled epoxidized natural rubber (ENR) composite and its properties. J Polym Environ. 21:245-258. DOI: 10.1007/s10924-012-0475-9.

Jirimali HD, Chaudhari BC, Khanderay JC, Joshi SA, Singh V, Patil AM, Gite V V. 2018. Waste eggshell-derived calcium oxide and nanohydroxyapatite biomaterials for the preparation of LLDPE polymer nanocomposite and their thermomechanical study. Polym - Plast Technol Eng. 57:804-811. DOI: 10.1080/03602559.2017.1354221.

Laohavisuti N, Boonchom B, Boonmee W, Chaiseeda K, Seesanong S. 2021. Simple recycling of biowaste eggshells to various calcium phosphates for specific industries. Sci Rep. 11:1-11.

Lee YK, Jung SK, Chang YH, Kwak HS. 2017. Highly bioavailable nanocalcium from oyster shell for preventing osteoporosis in rats. Int J Food Sci Nutr. 68:931-940. DOI: 10.1080/09637486.2017.1307948.

Li Z, Zhang Y, Tan T. 2009. Preparation of edible nano calcium lactate crystal from crude L-lactic acid via chemical precipitation method. J Biosci Bioeng.:S138. DOI: 10.1016/j.jbiosc.2009.09.015.

Mosaddegh E, Hassankhani A. 2014. Preparation and characterization of nano- $\mathrm{CaO}$ based on eggshell waste: Novel and green catalytic approach to highly efficient synthesis of pyrano[4,3-b]pyrans. Chinese J Catal. 35:351-356. DOI: 10.1016/S1872-2067(12)60755-4.

Nasrollahzadeh M, Sajadi SM, Sajjadi M, Issaabadi Z, Atarod M. 2019. An Introduction to Green Nanotechnology. Cambridge: Academic Press.
Nguyen NHA, Padil VVT, Slaveykova VI, Černík M, Ševců A. 2018. Green synthesis of metal and metal oxide nanoparticles and their effect on the unicellular alga Chlamydomonas reinhardtii. Nanoscale Res Lett. 13:113 .

Paschalis EP, Gamsjaeger S, Hassler N, Fahrleitner-Pammer A, Dobnig H, Stepan JJ, Pavo I, Eriksen EF, Klaushofer K. 2017. Vitamin D and calcium supplementation for three years in postmenopausal osteoporosis significantly alters bone mineral and organic matrix quality. Bone. 95:41-46. DOI: 10.1016/j.bone.2016.11.002.

Pongtonglor P, Hoonnivathana E, Limsuwan P, Limsuwan S, Naemchanthara K. 2011. Utilization of waste eggshells as humidity adsorbent. J Appl Sci. 11:3659-3662. DOI: 10.3923/jas.2011.3659.3662.

Prayitno AH, Suryanto E, Rusman. 2016. Pengaruh fortifikasi nanopartikel kalsium laktat kerabang telur terhadap sifat kimia dan fisik bakso ayam. Bul Peternak. 40:40-47. DOI: 10.21059/buletinpeternak.v40i1.9821.

Rivera EM, Araiza M, Brostow W, Castaño VM, DíazEstrada JR, Hernández R, Rodríguez JR, Díaz-Estrada J., Hernández R, Rodríguez JR. 1999. Synthesis of hydroxyapatite from eggshells. Mater Lett. 41:128-134. DOI: 10.1016/S0167-577X(99)00118-4.

Wang Y, Huang L, Wu J. 2012. Optimization of conditions for calcium lactate nano-particle production by chemical precipitation. Adv Mater Res. 479-481:314-317. DOI: 10.4028/www.scientific.net/AMR.479-481.314.

Wiria M, Tran HM, Nguyen PHB, Valencia O, Dutta S, Pouteau E. 2020. Relative bioavailability and pharmacokinetic comparison of calcium glucoheptonate with calcium carbonate. Pharmacol Res Perspect. 8:e00589. DOI: $10.1002 /$ prp2.589.

You Z, Xu J. 2021. Investigation on Variables Contributing to the Synthesis of C-S-H/PCE Nanocomposites by CoPrecipitation Method. Materials (Basel). 14:1-14. DOI: 10.3390/ma14247673.

Yuk HG, Jo SC, Seo HK, Park SM, Lee SC. 2008. Effect of storage in juice with or without pulp and/or calcium lactate on the subsequent survival of Escherichia coli O157:H7 in simulated gastric fluid. Int $\mathbf{J}$ Food Microbiol. 123:198-203. DOI: 10.1016/j.ijfoodmicro. 2008.01.013. 